\title{
Combined effects of chemical fertilization and microbial inoculant on nutrient use efficiency and soil quality indicators
}

\author{
Jimena Angulo1,* (D); María Mercedes Martínez-Salgado1,2,* ${ }^{\mathbb{D}}$; Rodrigo Ortega-Blu1 ${ }^{\mathbb{D}}$; \\ Paola Fincheira ${ }^{3}$ (D) \\ 1 Grupo de Investigación en Suelo, Planta, Agua y Ambiente (GISPA). Universidad Técnica Federico Santa María. \\ Santiago, Chile. \\ 2 TROPEN- Tropical Crops, Institute of Crop Science and Resource Conservation INRES Bonn Universität, Bonn \\ Germany Auf dem Hügel 6, 53121 Bonn, PC. 531113. \\ 3 Centro de Excelencia en Investigación Biotecnológica Aplicada al Medio Ambiente (CIBAMA), Facultad de Ingeniería \\ y Ciencias, Universidad de La Frontera, Av. Francisco Salazar 01145, Temuco, Chile.
}

Received April 22, 2020. Accepted June 8, 2020.

\begin{abstract}
Microbial inoculant based on beneficial bacteria is a complementary management tool to increase vegetable production. However, its integration with chemical fertilization has been poorly studied. The present study evaluated the effects of microbial inoculant separately and in combination with chemical fertilization on lettuce under greenhouse conditions. An experiment was performed in pots using a completely randomized design. The microbial inoculant was applied at three fertilization levels. Soil response evaluated variables were: available $N$ and $P$, total soil bacteria, soil enzymatic activities, and $\mathrm{N}$ leaching. Agronomic variables measured were: aerial biomass, chlorophyll content, and nutrient foliar contents. Microbial inoculant had a significant impact on soil total bacteria concentration. The application of reduced chemical fertilization and microbial inoculant had a similar effect in terms of soil nutrient availability and soil enzymatic activities as the complete fertilization. Nitrogen leaching was strongly dependent on chemical fertilization rate. Treatment application decreased chlorophyll concentration compared to the control. The application of microbial inoculant and chemical fertilization increased foliar $\mathbf{N}$ and $\mathrm{P}$ contents improving their uptake. The combined addition of microbial inoculant with chemical fertilization increases the bacteria concentration without altering enzymatic activities, maintaining similar soil nutrient levels and improving $\mathbf{N}$ and $P$ uptake in lettuce. Future studies could be performed in lettuce to determine the impact under different growth stages and different soil conditions.
\end{abstract}

Keywords: Microbial inoculant; chemical fertilization; nutrient efficiency; soil quality.

\section{Introduction}

The global human population has grown in recent years, and an important increase is projected towards 2050. In consequence, food demand will increase strongly (FAO, 2017). The application of agrochemicals in agriculture is seen as a necessary management to satisfy the food requirements (Good and Beatty, 2011). The demand for nutrient $\left(\mathrm{N}+\mathrm{P}_{2} \mathrm{O}_{5}+\mathrm{K}_{2} \mathrm{O}\right)$ consumption has increased over the years, reaching 200.522 million MT during 2018 (FAO, 2015). Nevertheless, only $30-50 \%$ of nitrogen is taken up by the crops. Consequently, surplus $\mathbf{N}$ generates environmental problems (Wang and Li, 2019). Moreover, excess chemical fertilization or fresh manure can have a negative impact on soil properties, altering the soil biota ecosystems, the plant-microorganism interactions, and water quality. The application of microbial inoculants constitutes a biotechnological tool to improve microbial ecology and plant nutrition, mitigating the negative impact of conventional chemical fertilization.

Microbial inoculants are biological products composed of viable beneficial microorganisms used to improve soil quality and plant nutrient status (Martínez, 2016; Pylak et al., 2019). Pseudomonas, Bacillus, Azospirillum, and Azotobacter are the main genera of

Angulo, J.; Martínez-Salgado, M.M.; Ortega-Blu, R.; Fincheira, P. 2020. Combined effects of chemical fertilization and microbial inoculant on nutrient use efficiency and soil quality indicators. Scientia Agropecuaria 11(3): $375-380$. 
benefic bacteria that induce plant growth (Ferreira et al., 2019). Soil-applied microorganisms can increase plant-growth by nitrogen fixation, phosphate solubilization, exudation of plant hormones, production of siderophores, and production of substances that inhibit plant pathogens (Martínez and Martínez, 2007; Glick, 2012). In particular, bacterial inoculants consortia containing the species Acidovorax facilis, Bacillus licheniformis, $B$. subtilis, $B$. oleronius, $B$. marinus, $B$. megatherium and Rhodococcus rhodochorus have been evaluated in tomato, pumpkin, corn, and broccoli, among others (Agricen, 2020). The reported beneficial effects of bacterial consortia are, among others, the increase in yield, root biomass, water retention capacity, and nutrient availability (Agricen, 2020). Therefore, the combination of appropriate rates of chemical fertilizer with microbial inoculants can have a significant positive impact on soil quality and crop yield (Bargaz et al., 2018; Lin et al., 2019; Ortega et al., 2020). Therefore, it is necessary to study the application of chemical fertilizers and microbial inoculants in vegetables of a commercial interest to optimize the fertilization-yield relationship. Based on the above the objective of the present work was to evaluate the impact of a bacterial inoculant and chemical fertilizer, and their combined application on soil properties and nutrition of lettuce (Lactuca sativa L.). It noteworthy pointing out that $L$. sativa is widely used as a model vegetable in horticulture to evaluate fertilization management due to its fast germination and growth, and easy management. Additionally, $L$. sativa has a great as it is widely consumed.

\section{Materials and methods}

\subsection{Plant material and experimental design} A greenhouse experiment was performed at the facilities of Federico Santa María University in Santiago, Chile. Plant material corresponded to seedlings of $L$. sativa $L$. var crispa $L$., which were planted on 2.3-L pots in a sandy soil. Selected soil properties are presented in Table 1. The experiment was performed under a completely randomized design. Six treatments were established to evaluate the effects of microbial inoculant application in the presence of chemical fertilization at three levels: 0,50 and $100 \%$ (Table 2). The evaluation was performed for 60 days. The chemical fertilization, at the complete rate, consisted in the application of an equivalent of 60,50 and $60 \mathrm{hg} \mathrm{ha}^{-1}$ of $\mathrm{N}$, $\mathrm{P}_{2} \mathrm{O}_{5}$, and $\mathrm{K}_{2} \mathrm{O}$, respectively. Microbial inoculant, consisted in a consortium of the following species: Acidovorax facilis, Bacillus licheniformis, $B$. subtilis, $B$. oleronius, $B$. marinus, $B$. megatherium and Rhodococcus rhodochorus (concentration $1 \times 10^{3} \mathrm{ufc} / \mathrm{ml}$ for each). The product was diluted at $1.2 \%$ in water for soil application (Agricen, 2020).

Table 1

Chemical characterization of the soil used for the experiment

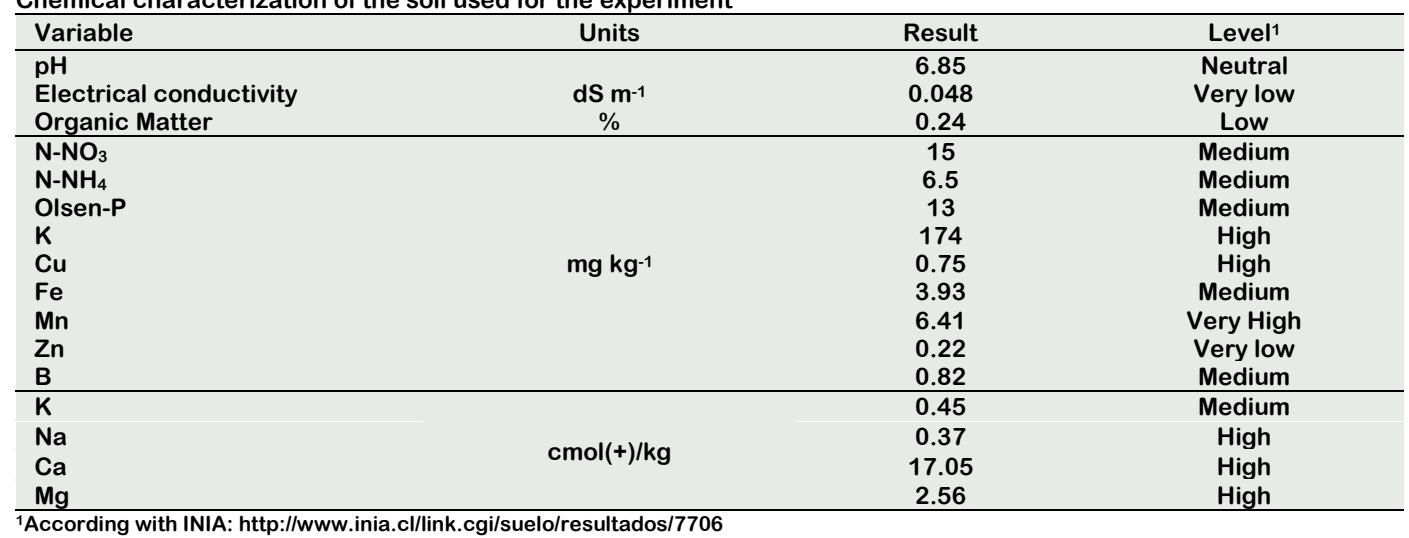

Table 2

Evaluated Treatments

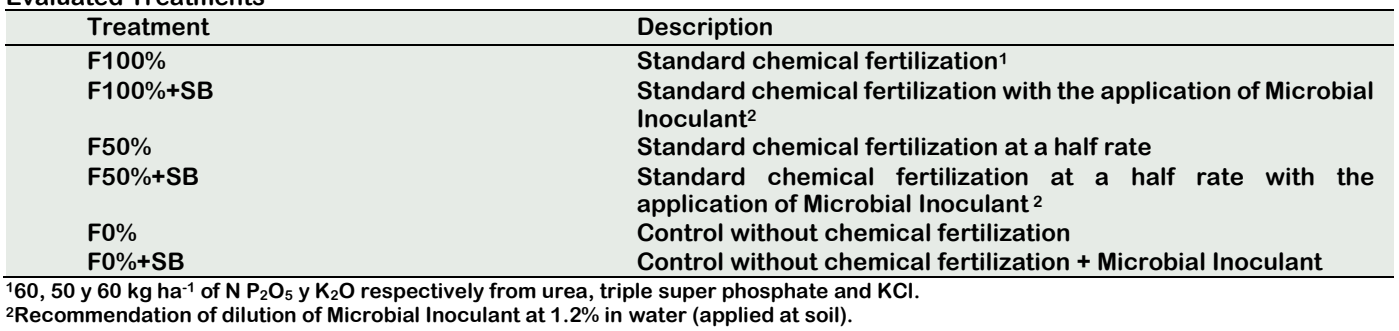




\subsection{Soil response variables}

Measured soil variables included available $\mathrm{N}$, extractable $\mathrm{P}$, and enzymatic activity. The quantification of nitrogen and phosphorus available was performed according to Sadzawka et al. (2006). Microbial populations were determined by the plate count (Martínez et al., 2010). The acid phosphatase activity was determined according to the methodology proposed by Tabatatai and Bremmer (1969). Dehydrogenase activity was determined according to Acosta and Paolini (2005). Urease activity was determined using the indophenol blue technique (García et al., 2003).

\subsection{Nitrogen in leachates}

All pots were irrigated with an equivalent amount of water to keep the soil near field capacity. Drained water was collected after each irrigation event from each pot, and stored at $4{ }^{\circ} \mathrm{C}$, before its analysis. Analysis of $\mathrm{NO}_{3}-\mathrm{N}$ in water was performed using the spectrophotometric method by direct quantification at $220 \mathrm{~nm}$ (Gvozdić et al., 2009). On the other hand, the quantification of $\mathrm{NH}_{4}-\mathrm{N}$ was performed by a colorimetric method (Mulvaney, 1996).

2.4 Leaf analysis and nutrient use efficiency Fresh vegetable tissues were decontaminated through sequential washes with $\mathrm{HCl}$ $(0.1 \mathrm{M})$ and sterile distilled water, and then dried at $70 \pm 5^{\circ} \mathrm{C}$ to determine root and leaf dry mass. Nutrients leaf concentrations were determined by the methods described by Sadzawka et al. (2007). Leaf total chlorophyll content was determined according to Lichtenthaler and Wellburn (1983).

\subsection{Statistical analysis}

Data were analyzed by analysis of variance (ANOVA) using the SAS software. Means were compared using protected Tukey test, with a significance level of $5 \%$.

\section{Results and discussion}

Sustainable agricultural practices for crop production are needed to ensure food security and environmental protection (McLaughlin and Kinzelbach, 2015). Chemical fertilizers have been widely applied to increase food production. On the other hand, the application of microbial inoculants constitutes a strategy to improve soil quality and plant nutrition (Martínez et al., 2010; Pylak et al., 2019). Recent studies have shown the important effect of the joint application of chemical fertilizer and microbial inoculants (Bargaz et al., 2018). A study performed by $Y e$ et al. (2020) reported that an inoculant containing Trichoderma species and reduced rate of chemical fertilizer increased tomato yield and it improved microbial activity in the soil. Moreover, Assainar et al. (2018) indicated that an adequate combination of microbial inoculants with rock-based fertilizer improved grain yield in maize under conditions of glasshouse. Nevertheless, there is not enough research on the effects of the joint application of both, chemical fertilizer and microbial inoculant on soil quality and plant nutrition. Ortega (2015) described this strategy as integrated nutrient management (INM), which included organic matter application, adjusted chemical fertilization, and microbial inoculants. In particular, Soil Builder ${ }^{\circledR}$, a commercial microbial inoculant, strongly decreases the emission of nitrous oxide $\left(\mathrm{N}_{2} \mathrm{O}\right)$ $(80 \%)$ in soils fertilized with urea-ammonium nitrate (Calvo et al., 2013). Afterward, Calvo et al. (2014) reported that Soil Builder ${ }^{\circledR}$ had an important growth-inducing effect, even under vegetables saline stress (i.e Cucurbita pepo) (Calvo et al., 2014).

Natural soil nutrient availability derives from organic matter (OM) mineralization mediated by microbial enzymatic activities, which degrade organic polymers to release nutrients for the root uptake (Dhaliwal et al., 2019). Often, OM mineralization is not enough to support high crop yields, and nutrients needs are supplied by chemical fertilizers. Our results showed that there were no statistically significant differences $(p<0.15)$ in nitrogen and phosphorus availability among treatments (Table 3). This effect could partly be explained by the high $\mathrm{N}$ leaching rates due to the sandy texture of the soil. Nitrogen losses were larger for the $\mathrm{F} 100 \%+\mathrm{SB}$ treatment, starting at day 15 (Figure 1). The larger $\mathbf{N}$ leaching observed in the treatments with microbial inoculant suggested an increase of urease activity.

Table 3

Soil quality indicators after treatment application

\begin{tabular}{|c|c|c|c|c|c|c|}
\hline Treatment & $\begin{array}{c}\text { P- } \\
\text { availability } \\
\left(\mathrm{mg} \mathrm{kg}^{-1}\right) \\
\end{array}$ & $\begin{array}{c}\mathrm{N}- \\
\text { availability } \\
\left(\mathrm{mg} \mathrm{kg}^{-1}\right)\end{array}$ & $\begin{array}{l}\text { Total bacteria } \\
\left(\log _{10} \text { UFC g-1) }\right.\end{array}$ & $\begin{array}{c}\text { APA } \\
\text { ( } \mu \mathrm{g} p \text {-nitrophenol } \\
\left.\mathrm{g}^{-1} \mathrm{~h}^{-1}\right)\end{array}$ & $\begin{array}{l}\text { Urease Activity } \\
\left(\mu \mathrm{g} \mathrm{NH} \mathrm{g}^{-1} \mathrm{~h}^{-1}\right)\end{array}$ & $\begin{array}{c}\text { DHA } \\
\left(\mu g_{\text {TFP }} g^{-1}\right. \\
\left.\text { day }^{-1}\right)\end{array}$ \\
\hline F100\% & $8.3 \pm 0.23$ & $12.6 \pm 4.27$ & $5.9 \pm 0.2 c$ & $66.0 \pm 7.58$ & $35.6 \pm 4.17 a b$ & $28.3 \pm 1.69$ \\
\hline F50\% & $9.2 \pm 0.48$ & $3.4 \pm 0.43$ & $6.2 \pm 0.2 b c$ & $29.7 \pm 1.71$ & $59.1 \pm 0.98 a$ & $30.8 \pm 1.04$ \\
\hline $\mathrm{F} 50 \%+\mathrm{SB}$ & $7.6 \pm 0.23$ & $9.7 \pm 3.19$ & $6.3 \pm 0.3 a b c$ & $40.1 \pm 0.84$ & $55.4 \pm 3.67 a b$ & $28.7 \pm 0.67$ \\
\hline F0\% & $11.5 \pm 0.31$ & $12.1 \pm 3.92$ & $7.1 \pm 0.1 \mathrm{a}$ & $40.7 \pm 2.69$ & $34.8 \pm 4.85 a b$ & $27.5 \pm 0.97$ \\
\hline$p$ value & 0.317 & 0.147 & 0.002 & 0.043 & 0.040 & 0.209 \\
\hline
\end{tabular}

Abbreviations: APA: Acid phosphatase activity; DHA: Dehydrogenase activity. 


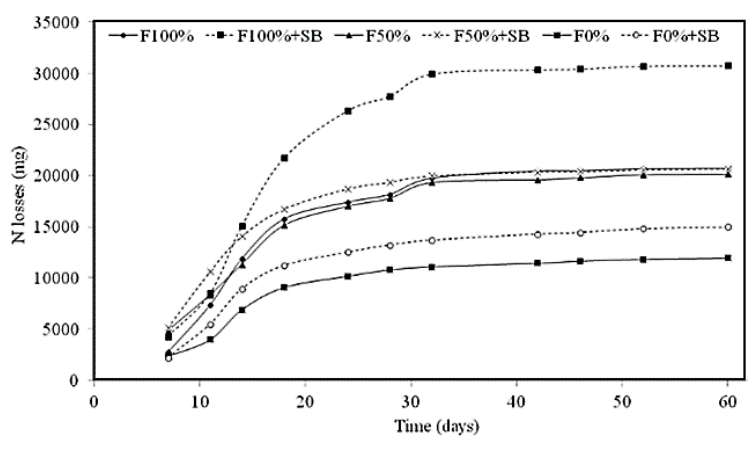

Figure 1. Nitrogen losses on water leached from pots.

Total bacterial population was higher in the treatments with no chemical fertilization in the presence or absence of microbial inoculant (Table 3). The inoculation effect was not detected by this variable, maybe because of the low concentration of each bacteria species in the product, $1 \times 10^{3} \mathrm{ufc} / \mathrm{ml}$ (Agricen, 2020).

Microorganisms release a variety of enzymes that act on soil organic matter increasing nutrient availability (Jacoby et al., 2017; Martínez et al., 2010). Phosphatase activity is an indicator of $P$ mineralization of soil. On the other hand, urease activity is an indicator of $\mathrm{N}$ bioavailability from organic sources such as urea and their precursors. Furthermore, dehydrogenase activity is an indicator of global soil metabolism. The results revealed that there were no significant differences in terms of enzymatic activities among treatments, which can be explained by the low organic matter content. Microorganisms need a source of energy (carbon) to properly develop and function in the soil. However, it was noted that urease activity tended to be higher in treatments with urea application. These results confirm the importance of adequate organic matter concentration together with the application of microbial inoculants (Martínez et al., 2010; Martínez, 2015).
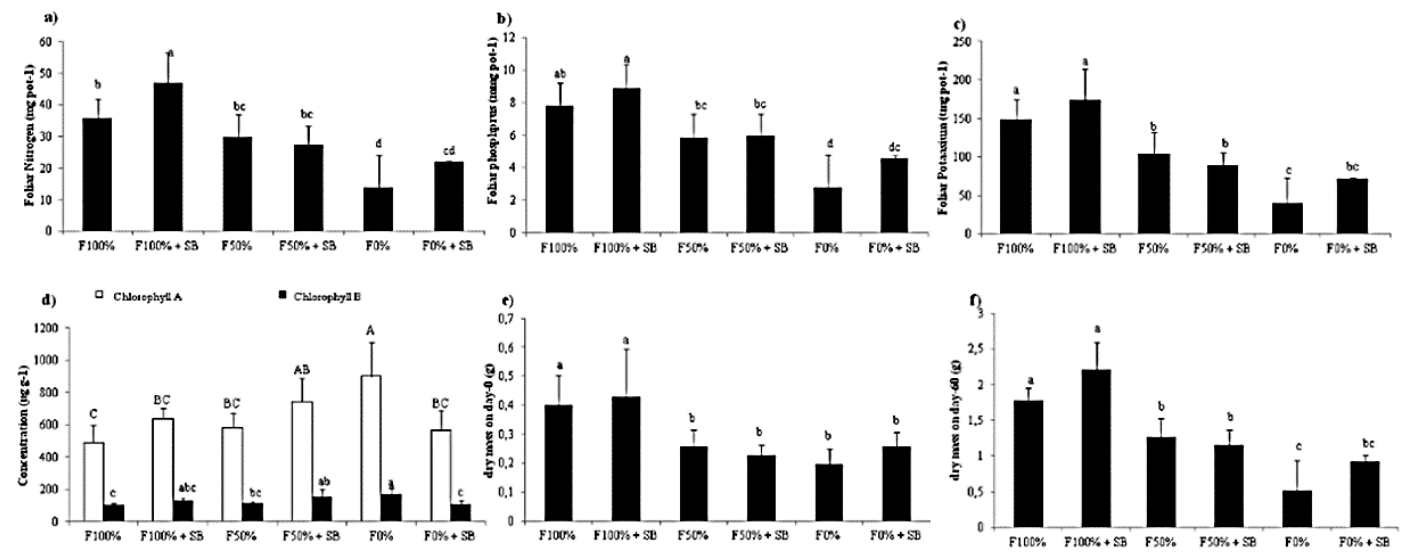

Figure 2. Leaf analysis of $L$. sativa after treatments application. The a) nitrogen, b) phosphorus and c) potassium absorbed. d) Chlorophyll A and B concentration. e-f). Root dry matter on day-0 and $60(p<0.001)$.
Leaf nutrient content is an index of nutrient absorption and its availability on soil (FAO, 2006). The results indicated that treatment with microbial inoculant and high fertilization rate significantly increased absorbed $\mathrm{N}$ by plants $\left(46.82 \mathrm{mg} \mathrm{pot}^{-1}\right)$, which probably were associated with the urea mineralization capacity of the microbial inoculants (Figure 2a). A similar tendency was found for the $P$ and $K$ absorption, although the effect of the inoculant was rather poor, probably because of the lack of sufficient organic matter to be mineralized by microorganisms (Figure 2bc). Besides, we analyzed the chlorophyll, which is a fundamental molecule to the photosynthesis process. Interestingly, the treatment without fertilization reached the largest chlorophyll content $(899.4 \mu \mathrm{g} \mathrm{g}$ 1 of chlorophyll A and $169.0 \mu \mathrm{g} \mathrm{g}^{-1}$ of chlorophyll B), probably because of a concentration effect (Figure 2d). The yield of a crop is measured by the dry mass of the economically important organ harvested (i.e aerial biomass in lettuce) (Figure 2e). Besides, root dry matter is an indicator of the plant capacity for nutrient absorption. Results showed significant differences among the fertilization levels but not between the presence or absence of the inoculant (Figure 2f). The nutrient use efficiency is given by the nutrient availability and root density.

This study demonstrated that the use of a bacteria consortia significantly increased the $N(p<0.001), P(p<0.002)$ and $K(p<$ 0.001 ) use efficiency, reaching 55,28 , and $267 \%$ (Figure 3ac). The absorption efficiency indicated that added microorganisms in conjunction with chemical fertilizer promote improved nutrient use efficiency, usually associated to larger root density (Ortega and Fernandez, 2007; Poblete et al., 2013; Martínez et al., 2019). In our experiment we were unable of detecting changes in root density, probably because of the method used. 


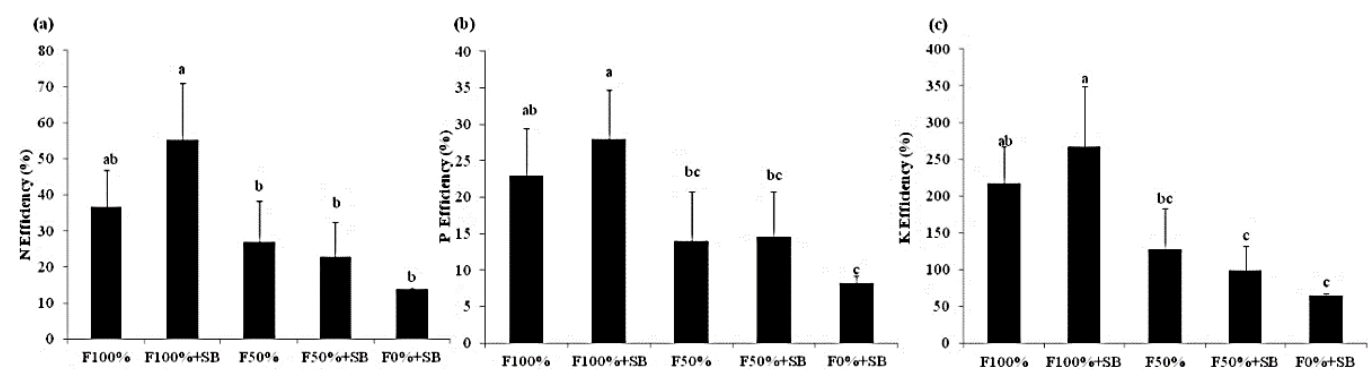

Figure 3. Nutrient use efficiency: a) nitrogen, b) phosphorus and c) potassium $(p<0.001)$.

\section{Conclusions}

Diverse studies have reported the important role of microbial inoculants to increase soil quality and nutrient use efficiency. The results of the present investigation showed that chemical fertilization treatments had a strong effect on the absorption of nutrients. Microbial inoculant significantly improved the nutrient use efficiency, despite the nonincrease in lettuce dry matter. The low microbial concentration in the product and/or low organic matter content in the soil, probably were the limiting factors controlling microorganism's and metabolites activity in the soil. The increase of available $\mathbf{N}$ by the simultaneous application of chemical fertilizer and inoculant was detected only in the leachates. Future studies must be carried out to determine the impact of these treatments on soil quality and productivity in the long and short-term during the growth cycle of lettuce.

\section{Acknowledgements}

The authors acknowledge the Company ASP Chile for funding this research. Thanks, are given to $\mathrm{Mr}$. Jorge Lundstedt for his valuable help for this work.

\section{ORCID}

J. Angulo $(\mathbb{D}$ https://orcid.org/0000-0002-9538-1891 M.M. Martínez-Salgado (D) https://orcid.org/0000-0001-9028-0752 R. Ortega-Blu $\mathbb{D}$ https://orcid.org/0000-0001-8294-1311

P. Fincheira $\mathbb{D}^{\mathbb{D}}$ https://orcid.org/0000-0002-6234-4808

\section{References}

Acosta, Y.; Paolioni, J. 2005. Actividad de la enzima deshidrogenasa en un suelo calciorthids enmendado con residuos orgánicos. Agronomía Tropical 55: 217-232.

Agricen. 2020. Ag Product - SoilBuilderTM. Available in: https://www.agricen.com/products/soilbuilder.

Assainar, S.K.; Abbott, L.K.; Mickan, B.S.; et al. 2018. Response of wheat to a multiple species microbial inoculant compared to fertilizer application. Frontiers in Plant Science 9: 1601.

Bargaz, A.; Lyamlouli, K.; Chtouki, M.; et al. 2018. Soil microbial resources for improving fertilizers efficiency in an integrated plant nutrient management system. Frontiers in Microbiology 9: 1606.

Calvo, P.; Watts, D.B.; Ames, R.N.; et al. 2013. Microbialbased inoculants impact nitrous oxide emissions from an incubated soil medium containing urea fertilizers. Journal of environmental quality 42: 704712.

Calvo, P.; Nelson, L.; Kloepper, J.W. 2014. Agricultural uses of plant biostimulants. Plant and Soil 383: 3-41.

Dhaliwal, S.S.; Naresh, R.K.; Mandal, A.; et al. 2019. Dynamics and transformations of micronutrients in agricultural soils as influenced by organic matter build-up: A review. Environmental and Sustainability Indicators 1: 100007.

Ferreira, C.M.H.; Soares, H.M.V.M.; Soares, E.V. 2019. Promising bacterial genera for agricultural practices: An insight on plant growth-promoting properties and microbial safety aspects. Science of The Total Environment 682: 779-799.

Food and Agriculture Organization of the United Nations (FAO). 2006. Plant nutrition for food security: A guide for integrated nutrient management. $348 \mathrm{pp}$.

Food and Agriculture Organization of the United Nations (FAO). 2015. World fertilizer trends and outlook to 2018. 53 pp.

Food and Agriculture Organization of the United Nations (FAO). 2017. The future of food and agriculture Trends and challenges. $180 \mathrm{pp}$.

García, C.; Gil, F.; Fernández, T.; et al. 2003. Técnicas de análisis de parámetros bioquímicos en suelos: Medida de actividades enzimáticas y biomasa microbiana. 371p. Ediciones Mundiprensa, Spain.

Glick, B.R. 2012. Plant Growth-Promoting Bacteria: Mechanisms and applications. Scientifica 2012: 963401.

Good, A.G.; Beatty, P.H. 2011. Fertilizing nature: A tragedy of excess in the commons. PLoS Biology 9(8): e1001124.

Gvozdić, V.; Tomišić, V.; Butorac, V.; et al., 2009. Association of nitrate ion with metal cations in aqueous solution: a UV-Vis spectrometric and factoranalytical study. Croatica Chemica Acta 82(2): 553559.

Jacoby, R.; Peukert, M.; Succurro, A.; et al. 2017. The Role of Soil Microorganisms in plant mineral nutrition- Current knowledge and future directions. Frontier Plant Sciences 8: 1617.

Lichtenthaler, H.K.; Wellburn, A.R. 1983. Determination of total carotenoids and chlorophylls $a$ and $b$ of leaf extracts in different solvents. Biochemical Society Transactions 11(5): 591-597.

Lin, W.; Lin, M.; Zhou, H.; et al. 2019. The effects of chemical and organic fertilizer usage on rhizosphere soil in tea orchards. PLoS ONE 14(5): e0217018.

Martínez, M.; Gutiérrez, V.; Novo, R. 2010. Microbiología aplicada al manejo sustentable de suelos y cultivos. Ed. Universidad Santa Maria, Chile. 235 pp.

Martínez M. 2015. Microbial bioproducts for agriculture. Acta Horticulturae 1076(1076): 71-76

Martínez, M.; Martínez, A. 2007. Effects of phosphatesolubilizing bacteria during the rooting period of sugar cane (Saccharum officinarum), Venezuela 51-71 variety, on the grower's oasis substrate. In: Velázquez E., Rodríguez-Barrueco C. (eds) First International Meeting on Microbial Phosphate Solubilization. Developments in Plant and Soil Sciences, vol 102. Springer, Dordrecht. 
McLaughlin, D.; Kinzelbach, W.2015. Food security and sustainable resource management. Water Resourse Research 51: 4966-4985.

Mulvaney, R.L. 1996. Nitrogen: Inorganic Forms. 11231184 p. In Methods of Soil Analysis, Part 3, Chemical Methods. Sparks, D.L.; Page, A.L.; Helmke, P.A.

Ortega, R.; Fernandez, M. 2007. Agronomic evaluation of liquid humus derived from earthworm humic substances. Journal of Plant Nutrition 30(12): 2091 2104.

Ortega, R. 2015. Integrated nutrient management in conventional intensive horticulture production systems. Acta Horticulturae 1076: 159-164.

Ortega-Blu, R.; Martínez-Salgado, M.M.; Ospina, P.; et al. 2020. Nitrate Concentration in Leafy Vegetables from the Central Zone of Chile: Sources and Environmental Factors. J Soil Sci Plant Nutr (/n press).

Poblete, H.; Martínez, M.; Ortega, R. 2013. Integrated plant nutrition on the recovery of a pear (Pyrus communis 'Packam'S Triumph') orchard. Acta Horticulturae 1076: 179-186.

Pylak, M.; Oszust, K.; Frac, M. 2019. Review report on the role of bioproducts, biopreparations, biostimulants and microbial inoculants in organic production of fruit. Reviews in Environmental Science and Bio/Technology 18(3): 597-616.

Sadzawka, A.; Carrasco, M.; Grez, R.; et al. 2006. Recommended analysis methods for Chile soils Review 2006. Series INIA records N ${ }^{\circ} 34$. Institute of Agricultural Research. Chile. 164 pp.

Sadzawka, A.; Carrasco, M.; Demanet, R.; et al. 2007. Methods of analysis of plant tissues. Series INIA records No. 40. Institute of Agricultural Research. Santiago. Chile. 120 pp.

Tabatatai, M.; Bremmer, J. 1969. Use of p-nitrofenyl phosphate for assay of soil phosphatase activity. Soil Biology and Biochemistry 1(4): 301-307.

Wang, Z.H.; Li, S.X. 2019. Chapter Three - Nitrate N loss by leaching and surface runoff in agricultural land: $A$ global issue (a review). Advances in Agronomy 156: 159-217.

Ye, L.; Zhao, X.; Bao, E.; et al. 2020. Bio-organic fertilizer with reduced rates of chemical fertilization improves soil fertility and enhances tomato yield and quality. Scientific Reports 10: 177. 